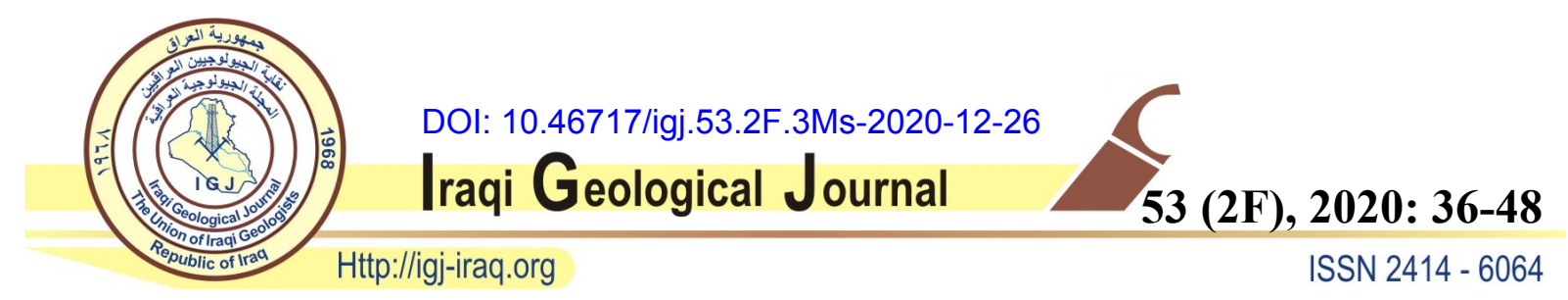

\title{
PHYSICAL AND ENVIRONMENTAL EFFECTS OF GROUNDWATER TABLE RISING IN AJDABIYA, NORTHEAST LIBYA
}

\author{
${ }^{1}$ Saleh Emhanna*, ${ }^{2}$ Fathi Elkaseh, ${ }^{1}$ Hassan Douas and ${ }^{1}$ AbdulHamid Al-Hwaili \\ ${ }^{1}$ College of Engineering, / University of Ajdabiya, Libya \\ ${ }^{2}$ Engineering at Electricity Company, Ajdabiya, Libya \\ *E- mail: salehemhanna@uoa.edu.ly
}

Received:15 July 2020; accepted:15 October 2020

\begin{abstract}
The rising groundwater levels in Ajdabiya city have been considered one of the critical issues that the city suffered for years, where it is attributed to a lot of undesirable environmental and physical effects. Deterioration of infrastructure facilities led to health and economic consequences in different areas. The study aims to identify the causes effects and feasible strategies to mitigate them. There are Many causes led to rising the groundwater level such as the leakage of domestic water pipeline and sewage network. It noted an absence of a rainwater drainage network and the adoption of only surface water for daily life usages. Furthermore, never ever the groundwater has been not exploited, which led to upward seepage more and more. Ten groundwater samples have been collected to conduct specific criteria which proved the mixing between the groundwater and sewage. Many projects can be adapted to maintain the groundwater upward seepage and manage the water supplies in the area using the conjunctive use of groundwater and surface water to optimize the water demand. The most important is avoiding all pollutants whether surface or/and subsurface by maintaining the sewage network and drainages. For a more comprehensive image, it is recommended to adopt geotechnical tools before suggesting the management plan.
\end{abstract}

Keywords: Groundwater table; Upward seepage; Environmental and physical effects; Infrastructure deterioration; Health and economic consequences

\section{INTRODUCTION}

Groundwater has long been and continues to serve as a reliable source of water for a variety of purposes, including industrial and domestic uses and irrigation. Groundwater is not static. It is part of a dynamic flow system. It moves into and through aquifers from areas of high water-level elevation to areas of low water elevation. Groundwater table fluctuates seasonally and temporally based on the consumption and (dis)-recharge areas due to addition or 
extraction of water from the aquifer, both through natural means and human involvement (AlSefry and Al-Şen, 2006). Hadi and Alwan (2020) mentioned that the levels of shallow groundwater depend on several factors such as the topography, type of the soil, Wastewater sources, land use nature, and rainfall amount in the area. When recharge occurs in an unconfined aquifer, the water table rises to a higher elevation. A trend of rising groundwater level has been anecdotally observed in Ajdabiya city over the last 10 years. Associated with this rising groundwater is the potential for several geohazards to occur, which can cause significant nuisance and cost through damage to the built and urban environments. Fayydh et al. (2020) mentioned that the high concentrations of cations and anions in the groundwater of the study area may be due to change of oxidation and reduction conditions, and also to the natural geogenic influences of infiltration and pervade. Al-Harahshah et al. (2020) mentioned that the GW genesis and elemental composition can be altered and determined by the rock/water interactions and ion exchange processes. Understanding and predicting changes in groundwater level is a critical part in the long-term management of a groundwater resource. Sustainable groundwater management requires a variety of sources of data over an adequate period of time in order to inform water resource planners, managers and urban developers (Yihdego et al, 2017). Insufficient data increases the risk to the aquifer system and associated groundwater dependent environment as well as causing problems for current and future urban development (Foster and Hirata, 2011). Although it is unclear that the causes of groundwater table rising are naturally or just by human made activates, the study highlighted on the potential reasons of groundwater table rising and the risks of the consequences and then suggested solutions.

This study aims to review the following:

1. Highlighting the impact of rising groundwater on the environment, human health, roads and infrastructure facilities in Ajdabiya city.

2. Highlighting the causes of rising groundwater levels in the Ajdabiya region.

3. Investigate the effect of geology on the rising of groundwater in Ajdabiya city.

\section{Statement of the Problem}

The rising of the groundwater table is considered one of the most dangerous problems that threaten the underground structures. As the city suffers from this serious problem, which may cause an environmental deterioration to the infrastructure of facilities and services, where the groundwater seepage reaching the communication and electricity underground networks. There are areas where the water table has reached the earth's surface such as the city's sports 
hall and some houses and streets in the city (Fig. 1). Therefore, the accurate diagnosis of the causes makes us able to deal with it.

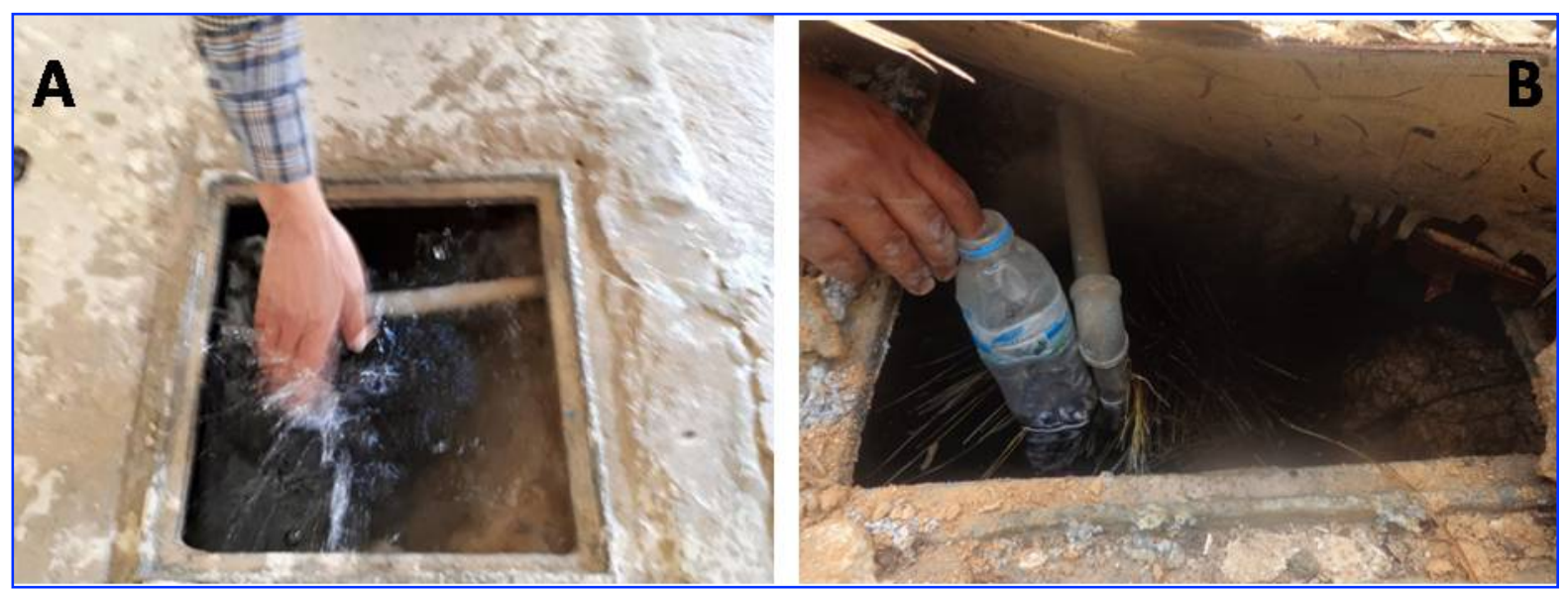

Fig. 1. Groundwater table rising in the sampling point hole in a house near Al-weifaq football club (A) February 2019 and (B) February 2020

\section{HYDROGEOLOGY}

\section{Geology}

Determination of lithology and rock properties for the subsurface beds is important in studying the reasons of surface soil damp and upward seepages of groundwater. There are eleven sediment samples have been collected by the sampling holes, the area consists of limestone with a high porosity. The lithology varied from calcarenite limestone in the southeastern region of the city to fossiliferous limestone in the north and southwest (Fig. 2). Most of the samples in this study are characterized by medium to high porosity and the porosity ranges from $5 \%$ to $30 \%$. This high porosity helps in the movement of groundwater through them.
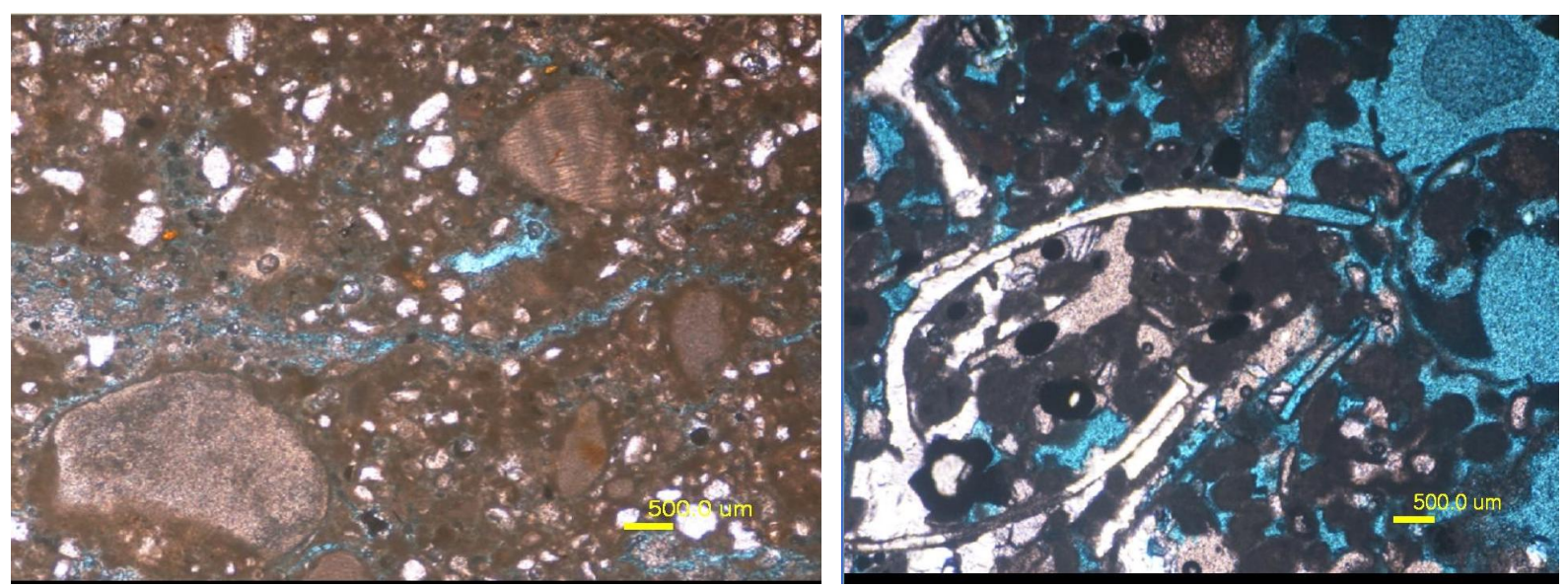

Fig. 2. Thin sections of the limestone, calcarenite limestone (left) and fossiliferous limestone (right) 


\section{Topographical Map}

Topographical map shows elevation of the Earth's surface and also shows the dipping of the city in the NE direction (Fig. 3). The surface elevation in the city from datum (Sea level) and reaches up to 15 meters at the northwest of the city, which makes it closer to groundwater levels than the surrounding areas and also makes it a collection area for surface and groundwater flows, which increases the possibility of rising water levels by increasing the intensity of rain.

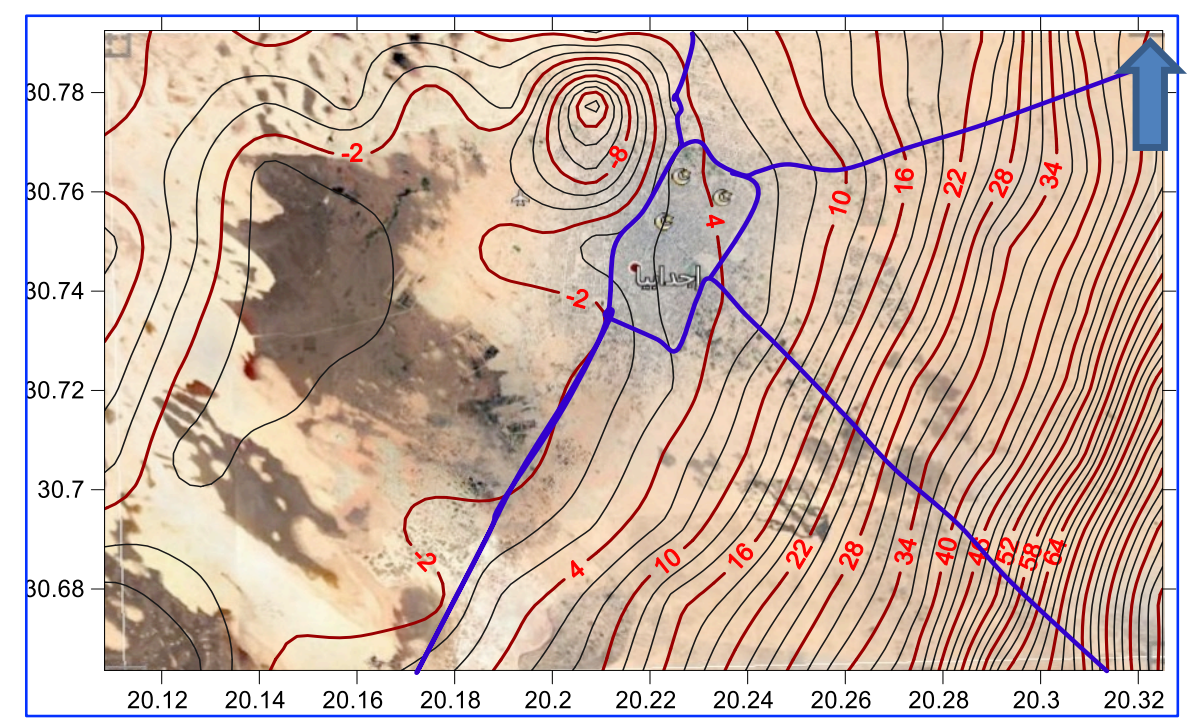

Fig. 3. Topographic map shows elevation of the Earth's surface and the

\section{Groundwater Table}

dipping in the NW direction

The groundwater table was measured at 18 wells during 2019 and 2020 (Fig. 4). Generally, the shallowest wells located in the NE direction and this confirm with the surface topography in the city. They show the depth of the groundwater between 0 and $5 \mathrm{~m}$ below the earth surface (Table 1).

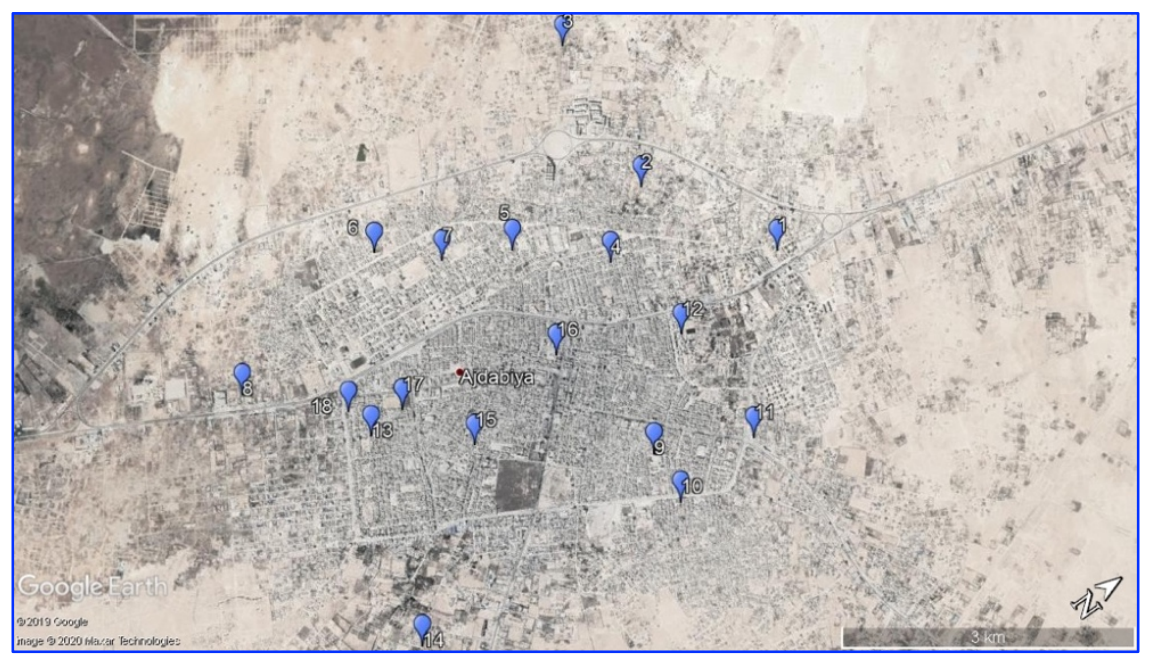

Fig. 4. Location of measured wells 
Table 1. Depth of groundwater in the 18 wells

\begin{tabular}{|c|c|c|c|}
\hline $\begin{array}{c}\text { Depth of groundwater from the surface } \\
(\mathbf{m})\end{array}$ & Longitude & Latitude & Location \\
\hline 2 & $20^{\circ} 13^{\prime} 34.10^{\prime \prime} \mathrm{E}$ & $30^{\circ} 46^{\prime} 52.24 " \mathrm{~N}$ & 1 \\
\hline 1.90 & $20^{\circ} 12^{\prime} 41.72^{\prime \prime} \mathrm{E}$ & $30^{\circ} 46^{\prime} 27.077^{\prime \prime} \mathrm{N}$ & 2 \\
\hline 3.80 & $20^{\circ} 11^{\prime} 36.32^{\prime \prime} \mathrm{E}$ & $30^{\circ} 46^{\prime} 34.34^{\prime \prime} \mathrm{N}$ & 3 \\
\hline 2 & $20^{\circ} 12^{\prime} 58.99^{\prime \prime} \mathrm{E}$ & $30^{\circ} 46^{\prime} 3.56^{\prime \prime} \mathrm{N}$ & 4 \\
\hline 2.50 & $20^{\circ} 12^{\prime} 32.26^{\prime \prime} \mathrm{E}$ & $30^{\circ} 45^{\prime} 38.66^{\prime \prime} \mathrm{N}$ & 5 \\
\hline 3 & $20^{\circ} 12^{\prime} 1.11^{\prime \prime} \mathrm{E}$ & $30^{\circ} 45^{\prime} 0.05^{\prime \prime} \mathrm{N}$ & 6 \\
\hline 4.20 & $20^{\circ} 12^{\prime} 19.32^{\prime \prime} \mathrm{E}$ & $30^{\circ} 45^{\prime} 17.12^{\prime \prime} \mathrm{N}$ & 7 \\
\hline 1 & $20^{\circ} 12^{\prime} 16.81^{\prime \prime} \mathrm{E}$ & $30^{\circ} 43^{\prime} 55.69^{\prime \prime} \mathrm{N}$ & 8 \\
\hline 3 & $20^{\circ} 14^{\prime} 10.15^{\prime \prime} \mathrm{E}$ & $30^{\circ} 45^{\prime} 37.60^{\prime \prime} \mathrm{N}$ & 9 \\
\hline 3.70 & $20^{\circ} 14^{\prime} 31.31^{\prime \prime} \mathrm{E}$ & $30^{\circ} 45^{\prime} 35.07 " \mathrm{~N}$ & 10 \\
\hline 4 & $20^{\circ} 14^{\prime} 27.63^{\prime \prime} \mathrm{E}$ & $30^{\circ} 46^{\prime} 7.55^{\prime \prime} \mathrm{N}$ & 11 \\
\hline 3.20 & $20^{\circ} 13^{\prime} 38.67^{\prime \prime} \mathrm{E}$ & $30^{\circ} 46^{\prime} 8.64^{\prime \prime} \mathrm{N}$ & 12 \\
\hline 2 & $20^{\circ} 12^{\prime} 59.78^{\prime \prime} \mathrm{E}$ & $30^{\circ} 44^{\prime} 23.15^{\prime \prime} \mathrm{N}$ & 13 \\
\hline 5 & $20^{\circ} 14^{\prime} 17.63^{\prime \prime} \mathrm{E}$ & $30^{\circ} 43^{\prime} 57.61 " \mathrm{~N}$ & 14 \\
\hline 2.80 & $20^{\circ} 13^{\prime} 26.37^{\prime \prime} \mathrm{E}$ & $30^{\circ} 44^{\prime} 49.79^{\prime \prime} \mathrm{N}$ & 15 \\
\hline 3 & $20^{\circ} 13^{\prime} 16.46^{\prime \prime} \mathrm{E}$ & $30^{\circ} 45^{\prime} 30.09^{\prime \prime} \mathrm{N}$ & 16 \\
\hline 0 & $20^{\circ} 12^{\prime} 58.61^{\prime \prime} \mathrm{E}$ & $30^{\circ} 44^{\prime} 37.06^{\prime \prime} \mathrm{N}$ & 17 \\
\hline 0 & $20^{\circ} 12^{\prime} 46.96^{\prime \prime} \mathrm{E}$ & $30^{\circ} 44^{\prime} 21.78^{\prime \prime} \mathrm{N}$ & 18 \\
\hline & & & \\
\hline
\end{tabular}

\section{RESULTS AND DISCUSSIONS}

\section{Causes of Rising Groundwater Table in the Ajdabiya City}

It is possible to summarize groundwater rise within the metropolitan area of Ajdabiya city due to the following causes:

1. Change in precipitation and lack of rain water drainage networks.

2. Excessive water consumption and non-use of groundwater.

3. Decaying sewage networks and leakage from the main sewage station.

4. Sabkha backfill.

5. Rising sea level

\section{Change in precipitation and Lack of rain water drainage networks}

Groundwater recharge occurs naturally where the earth materials are sufficiently permeable to allow water to move downward through them. It occurs most easily in unconfined aquifers where water provided by precipitation moves downward from land surface until the water reaches the water table. Direct influence on groundwater levels particularly after heavy rainfall events especially in case of lacking of rain water drainage networks, where a large amount of rain fell in the winter of 2019 compared to the rest of Libya. According to the National Meteorological Center the percentage reached $213 \mathrm{~mm}$. 

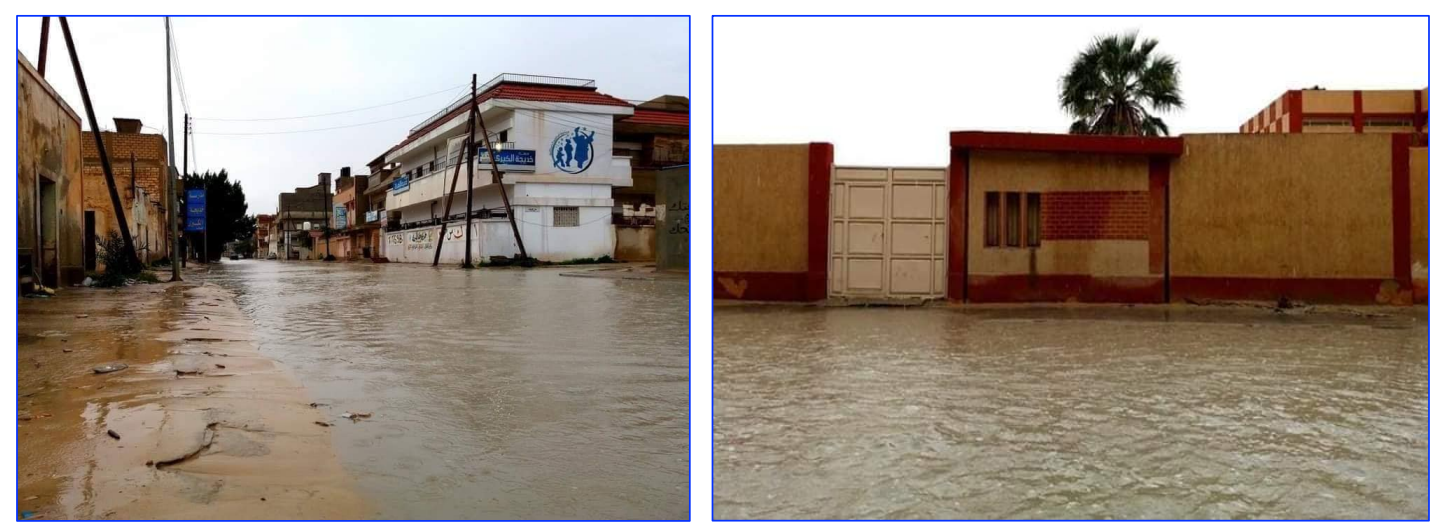

Fig. 5. Rain water in the streets in the Ajdabiya city, winter 2020

\section{Excessive water consumption and non-use of groundwater}

According to an official source from the man-made river project, the daily water supply to Ajdabiya city is about $55000 \mathrm{~m}^{3}$ and large percentage of this amount is distributed out of the water supply distribution system. Excessive consumption of the Man-made river water and cracks or loose binding locations along the pipelines (Fig. 6) comes at the forefront and the most important reasons of rising groundwater level throughout the city (river system). As what have been mentioned above the people in the city of Ajdabiya stopped using groundwater from the arrival of the man-made river water to the city since 1990. In this situation, if the underlying aquifer system is not used for irrigation and agriculture and/or the underlain beds not sufficiently permeable to transmit away the extra water, then groundwater levels will rise.

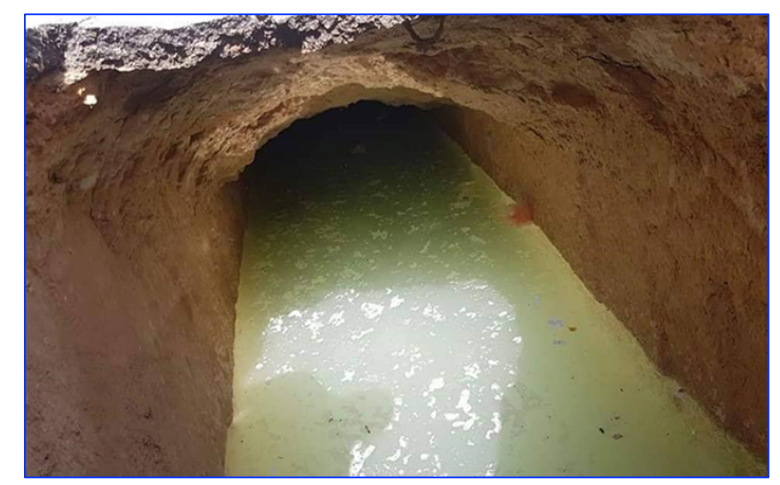

Fig. 6. Crack in the water supply network leads to landslide the street in the Al Briga street, Ajdabiya

\section{Decaying sewage networks and leakage from the main sewage station}

The sewage networks in the city are old and damaged and doesn't coverage the entire city (Fakhri and Fayez, 2004), especially new neighborhoods such as Damascus and Fallujah (Fig, 7). Where, the citizens in Ajdabiya city use dug wells (black wells) for sanitation that cause serious to groundwater Consequently, it led to polluted and fed groundwater and contributed greatly to its rise. 


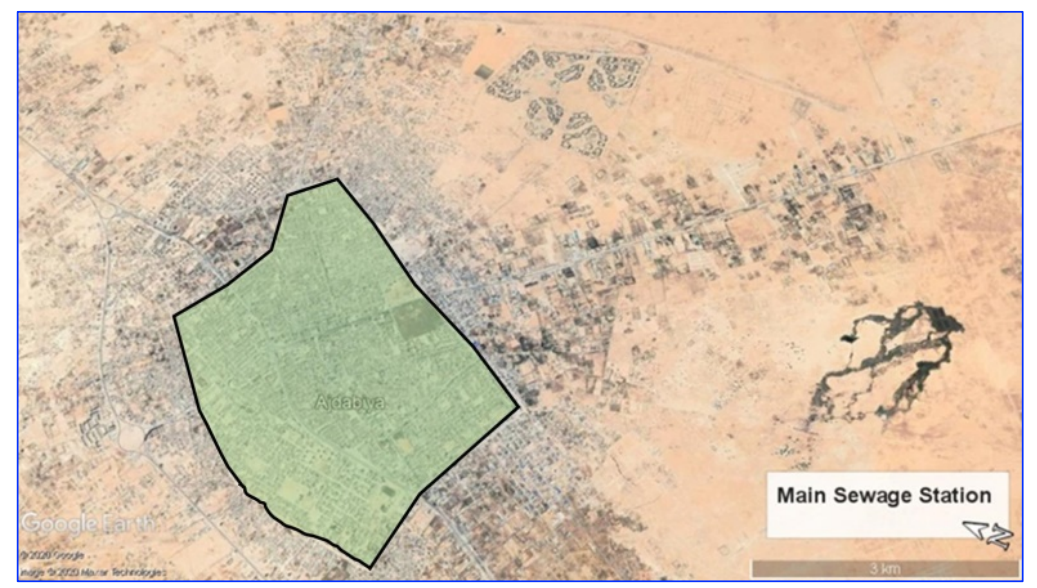

Fig. 7. Main sewage station and coverage sewage networks (green) in the city

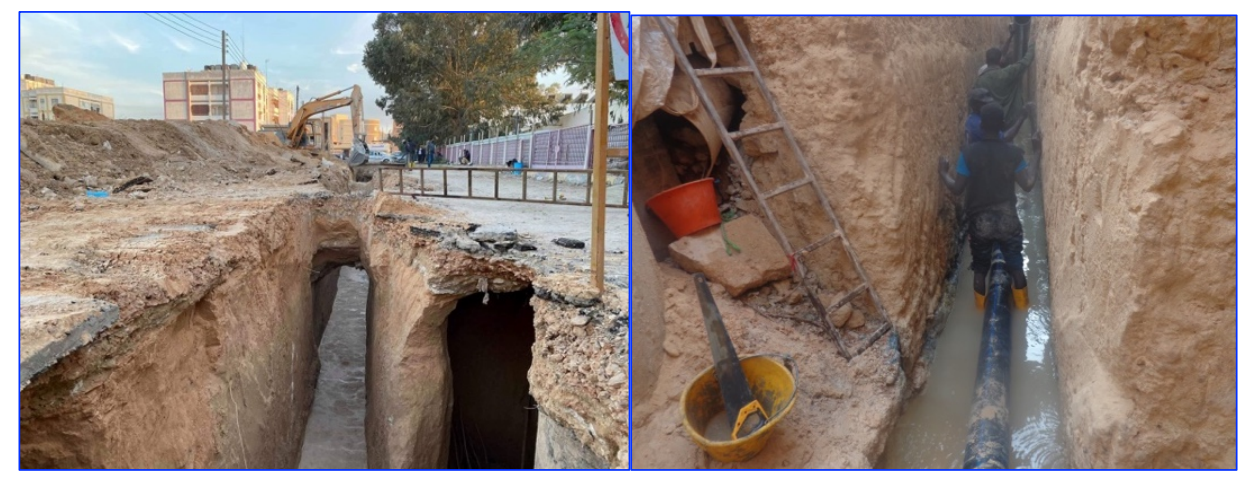

Fig. 8. Damaged in sewage networks pipe near the Ajdabiya University

Also, the main sewage station is far about $7 \mathrm{~km}$ south of Ajdabiya City at elevation about $38 \mathrm{~m}$. It was designed to treat $15,400 \mathrm{~m}^{3}$ of sewage. But, absence of water treatment station and re -use of the water produced in green fodder projects led to the sewage water return to the city with natural flow due to location of the station higher than the city level. The figure (7) has been taken from Google Earth for the Ajdabiya main sewage station on 24-22020. Observed the flow back of black water towards the city for a distance of $3.25 \mathrm{~km}$, as a result of the flood of the reservoir (tank).

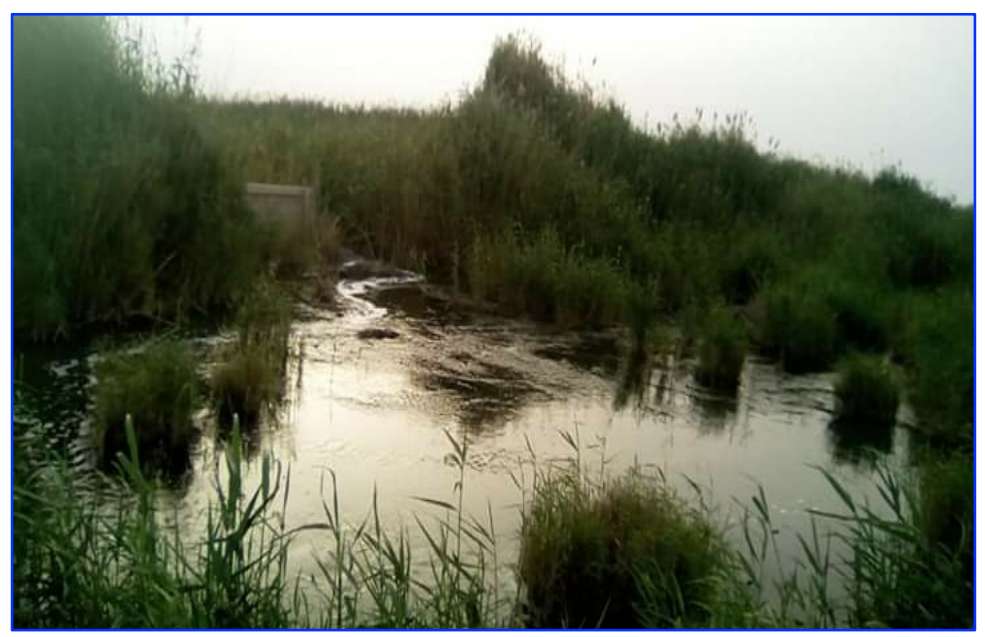

Fig. 9. Leakage of sewage water from the main sewage station 


\section{Sabkha backfill}

In recent years, as a result of the urban expansion, many of the sabkhas, which were operating as an outlet for groundwater, have been reclaimed, and this is one of the possible reasons for the rise of groundwater.

\section{Rising sea level}

Rising sea level is another reason for rising groundwater level in the city. According to the Bjerklie et al. (2012) study in the New Haven City, USA, the increasing sea levels will cause groundwater levels increasing. Where, geologically Ajdabiya City is low area as compared to neighbour areas and it will increase possibility of rising groundwater table, but they required extensive studies to confirm them.

\section{Geohazards Caused by Rising Groundwater}

The geohazards caused by rising groundwater in urban areas included damage to structures, damage to road and services, overloading of sewer system and treatment plants, salting and water logging of soils, and health hazards. More typical geohazards resulting from groundwater level rises can be considered to include landslides, ground subsidence, seismicity, gas emission, impacts on structures, mobilisation of pollutants and health hazards (George, 1992).

\section{Effects of rising groundwater on building and infrastructures}

Structural damage can occur with rising groundwater, particularly deep basements or shallow foundations. Principal causes of damage include: flooding, rising damp problems, reduce future urban development options and subsidence and crushing of pavement layers.

- Flooding

Flooding from groundwater can happen when the level of water within the rock that makes up the water table rises. Flood is caused by a combination of high ground water level and heavy rainfall causing water bodies to over flow their banks. The damage to property and infrastructure caused by groundwater flooding can be extensive and detrimental to the integrity of buildings. The flooding can cause people to move belongings or relocate and this has risk associated with it. Fig. 10 shows a house in the city affected by flooding during February 2019 and the same house became abandoned during February 2020. Flooding also causes stress and a longer impact on health, particularly for vulnerable sections of society.

- Rising damp problems

Rising damp is caused by the upward flow of moisture from the ground through the capillaries in the wall. Fig. 12 shows damp in the tunnel as result of the rising of groundwater level. 


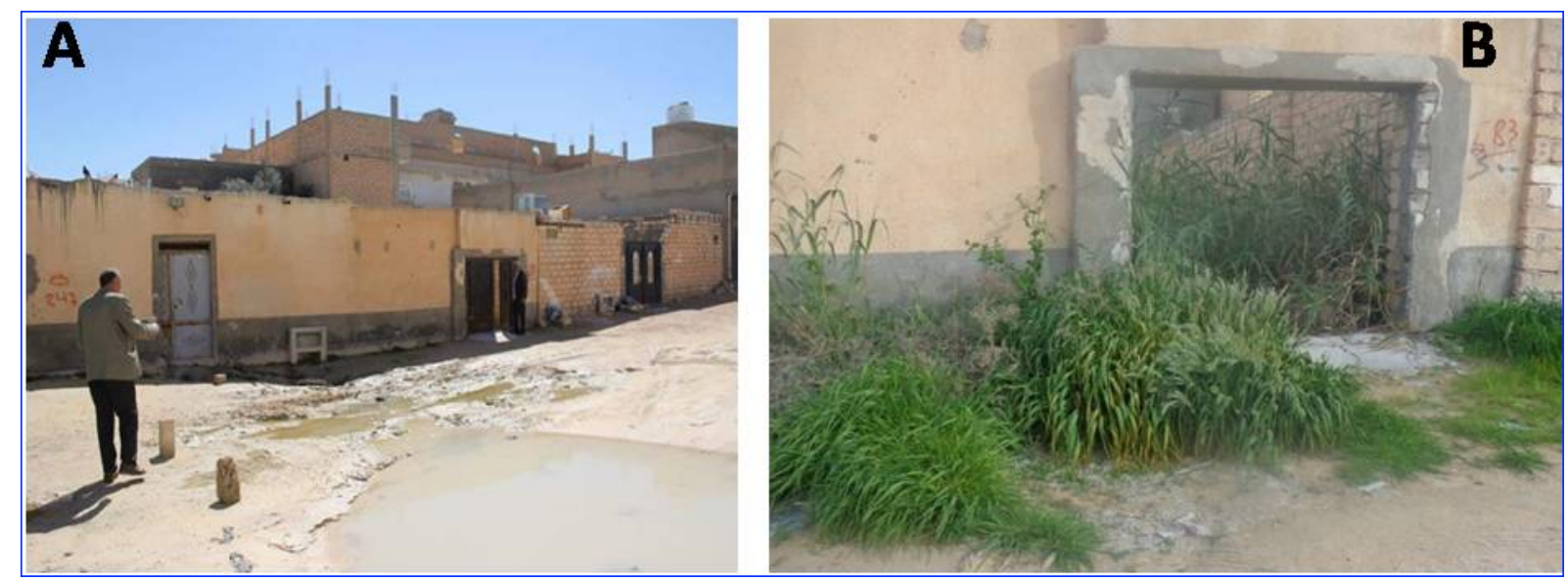

Fig. 10. Water flooding at homes near Al-weifaq football club (A) February 2019 and (B) February 2020

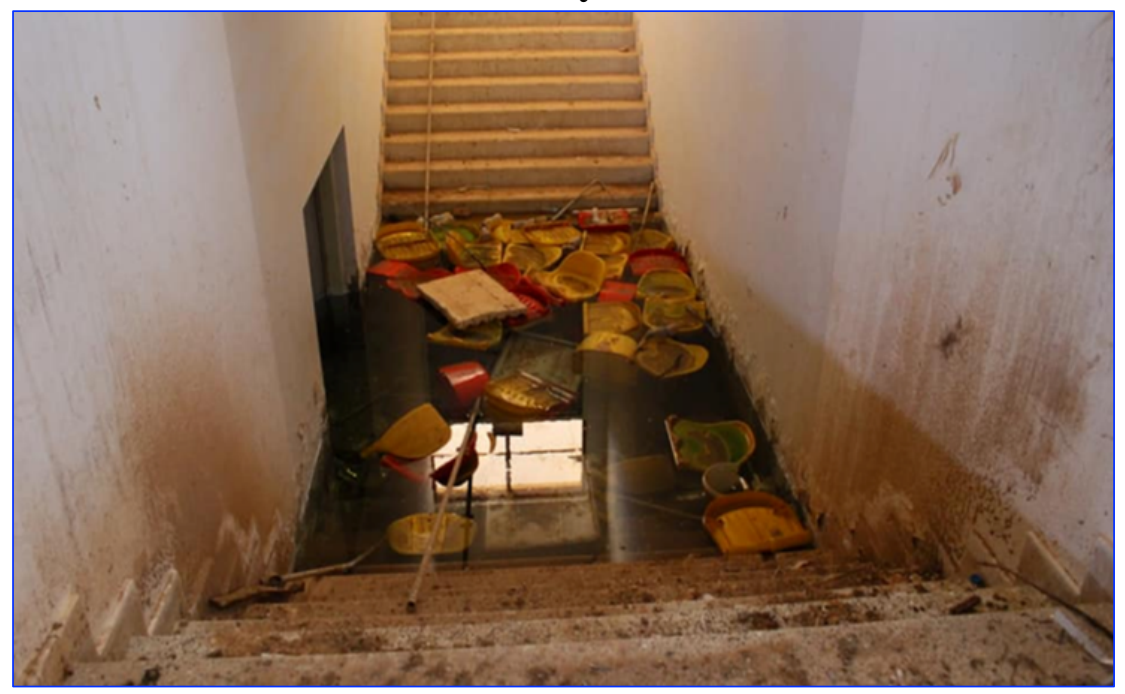

Fig. 11. Water flooding in the Ajdabiya Stadium

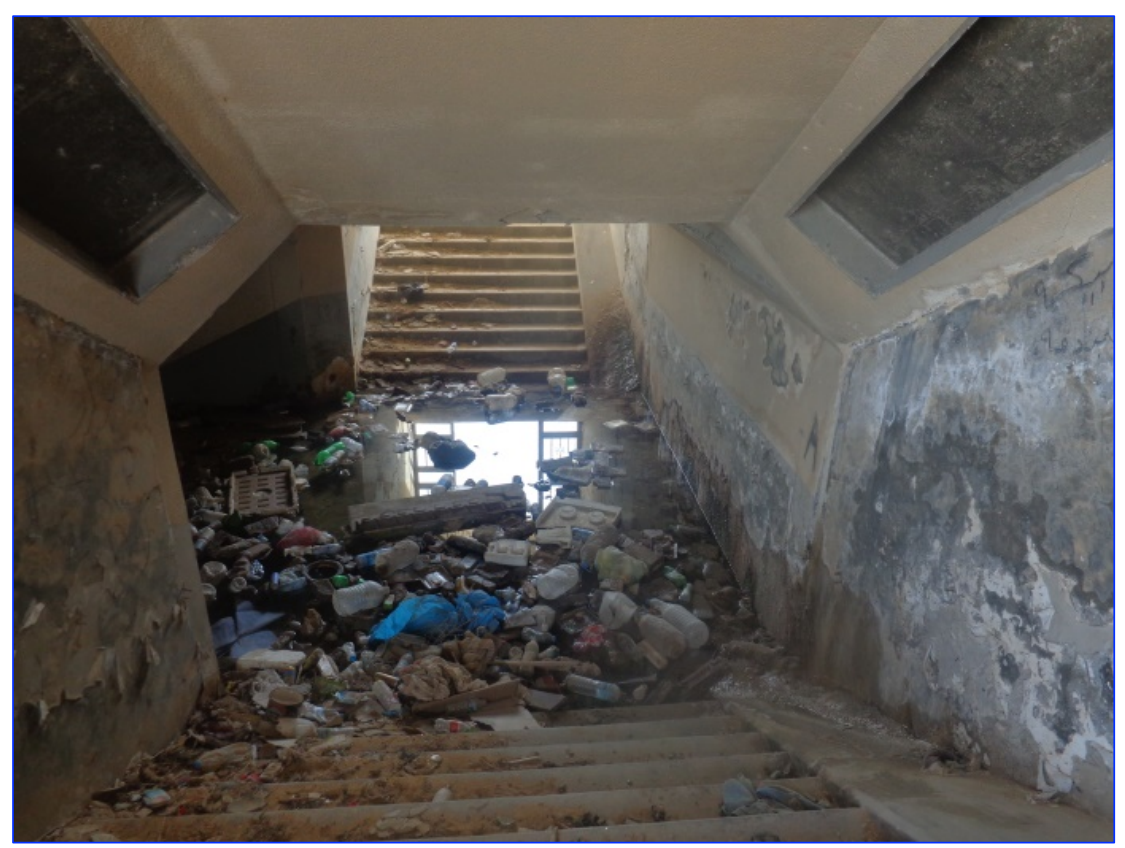

Fig. 12. Rising damp in the tunnels at Benghazi street 
- Reduce future urban development options

The rise of groundwater and it reaching the surface leads to the inability to use these lands for any residential or investment purpose (Fig. 13). On the contrary, the rise in the groundwater led to the spread of insects and, consequently, the spread of diseases.

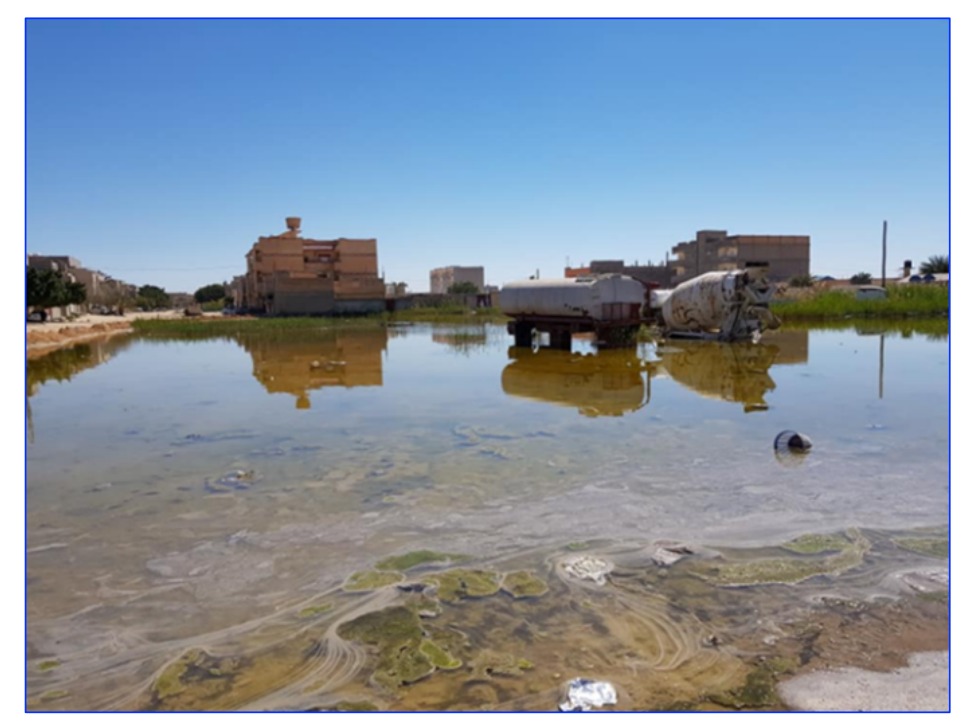

Fig. 13. Rising of groundwater to the surface behind Alnahdah school

- Subsidence and crushing of pavement layers

Rising groundwater level may induce/renew surface subsidence, which can be progressive or sudden over a wide area which in turn leads crushing of supply water network and collapse of pavement layers from the city center, in the middle of the street (Fig. 14).

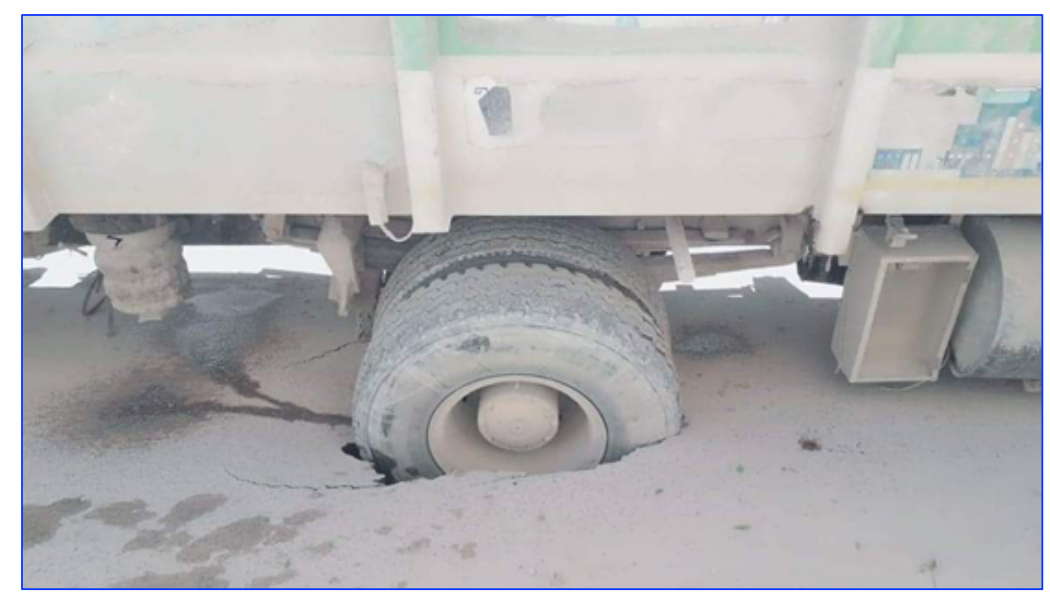

Fig. 14. Crushing of pavement layers

\section{Environmental and health risks}

As the water table rises pollutants may be mobilized causing new contamination problems. In extreme cases, where groundwater levels reach the surface, septic tanks may fail releasing pathogens, etc (Selim et al, 2014). In this study 10 samples from the water supply wells (Fig. 
15) have been analyzed and they indicated contamination of groundwater with wastewater. Tests were performed on three bacteria which represented Thekey Faecal indicator microorganisms, these are total coliform; Escherichia coli (E. coil) and Sptreptococcus Feacales (WHO, 2001).

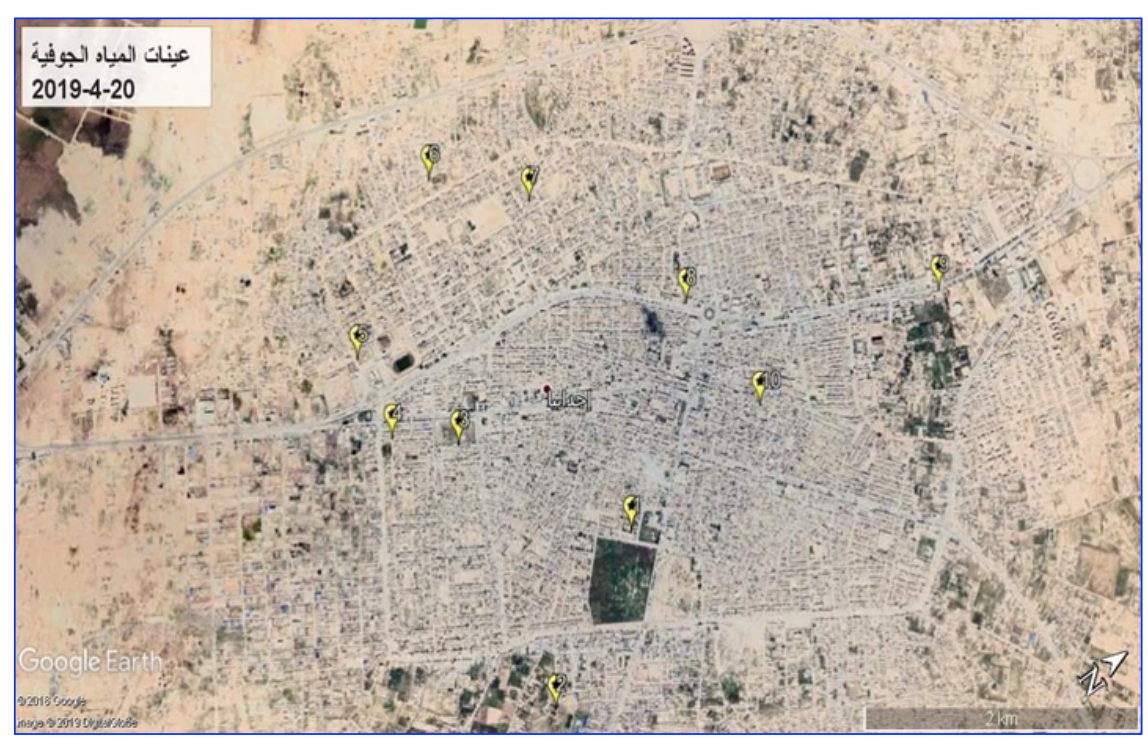

Fig. 15. Location of the 10 samples from the water supply wells

The total coliform bacteria were presented in all selected samples, and E. coli bacteria have founded in 5 wells, while Streptococcus were found in 8 wells. The highest concentration of the three types of bacteria was in Sample No. 3, due to the rise in groundwater and its connection to the surface of the land and thus its mixing with wastewater. These results are confirmed by Shaltami et al. (2020) study which mentioned the groundwater in the city are polluted with the sewage water.

Table 2. Microbial analysis of 10 samples from the water supply wells

\begin{tabular}{|c|c|c|c|}
\hline Sample & $\begin{array}{c}\text { Sptreptococcus } \\
\text { Feacales }\end{array}$ & $\begin{array}{c}\text { Escherichia coli } \\
\text { (E.coil) }\end{array}$ & Total coliform \\
\hline 1 & 13.9 & 25 & 28.8 \\
\hline 2 & 21.3 & 42.2 & 35.5 \\
\hline 3 & 148.3 & 456.9 & $>2419.6$ \\
\hline 4 & 1.00 & 0.00 & 343.6 \\
\hline 5 & 0.00 & 0.00 & 313.1 \\
\hline 6 & 14.8 & 28.8 & 165 \\
\hline 7 & 17.3 & 4.1 & 333.3 \\
\hline 8 & 1.00 & 0.00 & 190.4 \\
\hline 9 & 0.00 & 0.00 & 2.00 \\
\hline 10 & 13.4 & 0.00 & 178.9 \\
\hline
\end{tabular}




\section{CONCLUSIONS}

This study is concluded many important points:

- Rising groundwater levels in Ajdabiya City cause recent water logging issues. It has been anecdotally observed over the last 10 years and the rising results from combination of natural and human interference were driving the level up.

- Geologically, analysis of the rocks shows most of the city rock formations are limestone characterized by high porosity. Topographically, the rocks dipping in the NW direction, so this area is more affected by this problem.

- The main reasons for rising groundwater level in the city are; change in precipitation and lack of rain water drainage networks, excessive water consumption and non-use of groundwater, decaying sewage networks, the main sewage station leakage and there are other reasons such as rising sea level and backfill of sabkhas.

- Rising of the groundwater level in the city has great effects on buildings and infrastructures such as flooding, damp problems, reduce future urban development options and subsidence and crushing of pavement layers. In addition to environmental effects due to the rising of groundwater level, where the microbial analysis shows the groundwater contaminated with the sewage water, this may lead to an epidemic.

- Studying the problem in a scientific way ensures that the process of drawing water occurs in a safe way by calculating the amount of water that will be withdrawn accurately so as not to affect the infrastructure, because random drawing can lead to land subsidence or buildings fall.

\section{RECOMMENDATIONS}

- The necessity of conducting a comprehensive geotechnical and environmental study.

- Using groundwater in agriculture as well as reducing man made river leads to a drop-in water level.

- Control all human made activates and study the relation between each water body in the area like sabkhah, sea and industrial source with the groundwater using specific techniques case by case.

- Optimize the water demand and water balance supply between the surface water and groundwater... etc.

\section{REFERENCES}

Al Fakhiry, A and Fayez, A., 2004. The environmental effects of the Ajdabiya sewage station and sewage treatment, Environmental Journal: 22. 
Al-Harahshah, S., Al-Raggad, M., Al-Shdaifat, A., and Al-Wreikat, M., 2020. Hydrochemical evaluation of the azraq unconfined aquifer, Jordan. Iraqi Geological Journal, 35 (2A): 1-18.

Al-Sefry, S. and Al-Sen Z., 2006. Groundwater rise problem and risk evaluation in major cities of arid lands Jeddah case in Kingdom of Saudi Arabia. Water Resources Management, 20 (1): 91-108.

Bjerklie, D. Mullaney, J. Stone, J. Skinner, B. and Ramlow, M., 2012. Preliminary investigation of the effects of sea-level rise on groundwater levels in New Haven, Connecticut: U.S. Geological Survey Open-File Report, 46.

Fayydh, A. M., Zaidan, T. A., and Al- Heety, E. A. 2020. Evaluation of groundwater quality in al-waffa and kubaysa areas using multivariate statistical analysis, al-anbar, western Iraq. Iraqi Geological Journal, 35 (2D): 107-127.

Foster, S., and Hirata, R., 2011. Groundwater use for urban development: enhancing benefits and reducing risks. SIWI On-the-Water-Front, 21-29.

George, D. J., 1992. Rising groundwater: a problem of development in some urban areas of the Middle East. In: McCall G.J.H., Laming D. \& Scott, S. (eds), Geohazards-Natural and Man-Made. Chapman and Hall. London, 171- 182.

Hadi, S., and Alwan, H. H., 2020. Surface water-groundwater interaction in Dwaniya, southern Iraq using isotopic and chemical techniques. Iraqi Geological Journal, 53 (2B): 89-112.

Selim, S., Hamdan, A., and Rady, A., 2014. Groundwater rising as environmental problem, causes and solutions: case study from Aswan City, Upper Egypt. Open Journal of Geology, 4: 324-341.

Shaltami, O., Fares, F., El-Shari, S. El-Oshebi, F., Salloum, F., Favaloro, R., Alshelmani, N., Al-Maqrif, A., and Moftah, S., 2020. Assessment of drinking water quality and sanitation In Ajdabiya City, NE Libya. International Journal of Iraq. 53 (1B): 2020.

World Health Organization (WHO), 2001. Water quality: guidelines, standards and health. Edited by Lorna Fewtrell and Jamie Bartram. Published by IWA Publishing, London, UK. ISBN: 1900222280.

Yihdego, Y., Danis, C., and Paffard, A., 2017. Groundwater engineering in an environmentally sensitive urban area: assessment, landuse change/infrastructure impacts and mitigation measures. Hydrology, 4 (37). 